\title{
Noninvasive pre-natal diagnosis of sex by maternal cell-free plasma fetal DNA analysis
}

\author{
F.C.T.S. Boggian ${ }^{1}$, A.L.C. Pinto ${ }^{1}$, M.A. Silvestre ${ }^{1}$, J.C. Jaime, \\ K.S.F. e Silva ${ }^{2}$ and C.T. X. Silva ${ }^{1}$ \\ ${ }^{1}$ Department of Medicine, Centro Universitário de Anápolis, \\ UniEVANGÉLICA, Anápolis, GO, Brasil \\ ${ }^{2}$ Institute of Biological Sciences, Universidade Federal de Goiás, GO, Brasil \\ Corresponding author: C.T. X. Silva \\ E-mail: constanzathaise@yahoo.com.br \\ Genet. Mol. Res. 19 (2): gmr18559 \\ Received April 16, 2020 \\ Accepted May 31, 2020 \\ Published June 30, 2020 \\ DOI http://dx.doi.org/10.4238/gmr18559
}

\begin{abstract}
Fetal sexing from maternal plasma is aimed at early determination of fetal sex, and it is possible to detect in the maternal plasma specific alleles of the fetus, which are inherited paternally. In this case, specific Y chromosome sequences are amplified by PCR. This PCR technique is a useful tool for determining fetal sex, with no risk to the fetus. We determined fetal sex by molecular sexing technique at different gestational stages and compared the results with obstetric ultrasound information, in pregnant women between the 8th and 13th weeks of gestation, who were over 18 years of age. Among the 32 samples collected, 21 were females and 11 were males. Four samples showed false negative results, i.e., the Y chromosome DNA was not detected; however the fetus was male. All results incompatible with true fetal sex were collected from pregnant women at the 8th gestational week. In all four samples, the PCR failed to detect the Y chromosome. The determination of fetal sex from the 9th gestational week on had a satisfactory sensitivity index. The sensitivity and specificity of the tests increase with gestational age, making the test safe and with low probability of false negatives. The maternal cell-free plasma noninvasive test proved accurate for sex detection; it can be considered a practical alternative to traditional invasive diagnostic procedures.
\end{abstract}

Key words: Fetal sexing; Y chromosome; Maternal plasma and polymerase chain reaction - PCR 


\section{INTRODUCTION}

Circulating free fetal DNA in maternal plasma has been used for prenatal sexing. Its first description took place in 1966, where it was possible to obtain fetal karyotype from amniotic fluid cell culture, and in 1997 the presence of circulating free cell-free fetal DNA in maternal plasma was published. The most accepted theory for this phenomenon is the escape of trophoblast cells through the placenta. These cells would be destroyed either by the maternal immune system or by apoptosis, causing the release of fetal DNA into the maternal circulation (Almeida et al., 2014). This technique and research regarding it bring about earlier diagnosis of fetal conditions than current techniques in addition to its connection with diseases with a recessive $\mathrm{X}$-linked pattern of inheritance.

The amount of free fetal DNA is about 3 to $6 \%$ of the total circulating DNA in maternal plasma. These cells appear in the mother's circulation early, even in the first trimester of pregnancy, gradually increasing throughout pregnancy and being completely eliminated from maternal circulation after the delivery of the baby. Although these cells are present in both serum and plasma, plasma is the material of choice for analysis due to the lower concentration of maternal DNA (Hyett et al., 2005; Breveglieri et al., 2016).

These findings of fetal DNA in maternal plasma have led to promising initiatives in the development of noninvasive techniques for detecting X-linked diseases such as Duchene-type muscular dystrophy, color blindness and hemophilia, where female confirmation excludes the possibility of the fetus carrying such diseases. This makes it currently one of the most widely used applications of free and circulating fetal DNA for prenatal diagnosis, to determine fetal gender, with the primary objective of avoiding invasive diagnostic interventions (Sekizawa and Saito, 2001; Hyett et al., 2005).

Usually, the analysis of suspected genetic abnormalities is performed by an invasive technique through puncture of the uterus, extracting samples from amniocentesis and umbilical blood, which may incur serious risks to the development of the baby (Manualmsd, 2019). The use of free fetal DNA to detect chromosomal abnormalities in fetuses is still limited by the small percentage of free fetal DNA that is recovered from pregnant women's plasma. The fetal DNA fraction recovered represents approximately 5 to $10 \%$ of the total circulating DNA in maternal plasma during the first and third trimester of pregnancy. The efficiency of DNA extraction is directly related to the ability to detect DNA sequences according to the technique (Lo et al., 1998; Dhallan et al., 2004; Johnson et al., 2004).

The sexing according to the analysis of free fetal DNA in maternal plasma, contributes to the early disclosure of the fetus' gender and the exclusion of certain genetic diseases. However, this is still a costly and unavailable technique in the public health system, making most pregnant women choose to identify sex through ultrasound, with greater confidence from the 13th gestational week (Johnson et al., 2004).

The fetal sexing technique uses a sample of maternal peripheral blood in order to investigate free fetal DNA that during pregnancy crosses the placental barrier and reaches the bloodstream. The test aims to identify Y chromosome sequences in maternal plasma by PCR with Y chromosome-specific primer oligonucleotides. Since only male individuals have the $\mathrm{Y}$ chromosome, its detection suggests a boy and its absence, a girl (Zargari, 2011). In addition, the technique can be safely performed from the 8th week of pregnancy, which has sufficient amounts of fetal DNA in maternal plasma (Levi et al., 2003).

Our objective was to determine fetal sex through maternal plasma analysis, and evaluate the sensitivity and specificity of this method in pregnant women at different gestational ages and correlate the findings with obstetric ultrasound information. 


\section{MATERIAL AND METHODS}

This was a prospective, nonrandomized study, including pregnant women between the 8th and 13th weeks of gestation, over 18 years of age and without comorbidities. Patients who were interested in participating signed an informed consent form, containing all information about the research. This study was approved by the Research Ethics Committee of the Anapolis University Center - UniEVANGÉLICA (CAAE: 77893317.8.0000.5076).

Blood was collected from $5 \mathrm{~mL}$ of peripheral blood of pregnant women in an anticoagulant tube with EDTA, and homogenized at least five times. After this procedure, the blood was centrifuged at 5,000 rpm for about 10 minutes, aiming at the isolation of maternal plasma. It was stored in microtubes at a temperature of $-20^{\circ} \mathrm{C}$, for a maximum of 48 hours, to be used in the DNA extraction and PCR processes.

Isolation of fetal DNA was performed using the QUIAGEM extraction kit (QIAamp®) DNA blood Mini Kit). In this method, the plasma goes through an enzymatic lysis process, by means of proteinase $\mathrm{K}$, for stabilization of nucleic acids, thus increasing the selective adsorption of DNA to the microtube silica membrane. After this process, several washes are performed to remove impurities, and the pure DNA adhered to the silica membrane is then eluted in a suitable buffer and ready for use. The identified microtubes containing the DNA samples were stored at $4{ }^{\circ} \mathrm{C}$ until the PCR process was performed. The entire procedure was performed only by females in order to avoid external contamination with male DNA.

Subsequently, the isolated DNA material was subjected to PCR reaction using the materials described in Table 1, Y chromosome-specific Y7/Y8 primers (DYS14). The extracts were amplified in duplicate. Controls included two pregnant confirmed sex fetus patients, one normal male and one female fetus.

The DSY14 gene thermocycling protocol was performed with initial denaturation of $95^{\circ} \mathrm{C}$ for 5 minutes, followed by 35 cycles of $95^{\circ} \mathrm{C}$ for 1 minute, $55^{\circ} \mathrm{C}$ for 1 minute and $72^{\circ} \mathrm{C}$ for 1 minute and a final extension to $72^{\circ} \mathrm{C}$ for 7 minutes. PCR products were analyzed by ethidium bromide stained $2 \%$ agarose gel electrophoresis $(0.5 \mathrm{mg} / \mathrm{mL})$, a DNA intercalating compound that emits fluorescence when exposed to ultraviolet light. The $50 \mathrm{bp}$ ladder molecular weight standard (Invitrogen, Sao Paulo, Brazil) was used. The presence of one band corresponding to the 198 base pair Y chromosome fragment was interpreted as indicative of a male fetus (Figure 1).

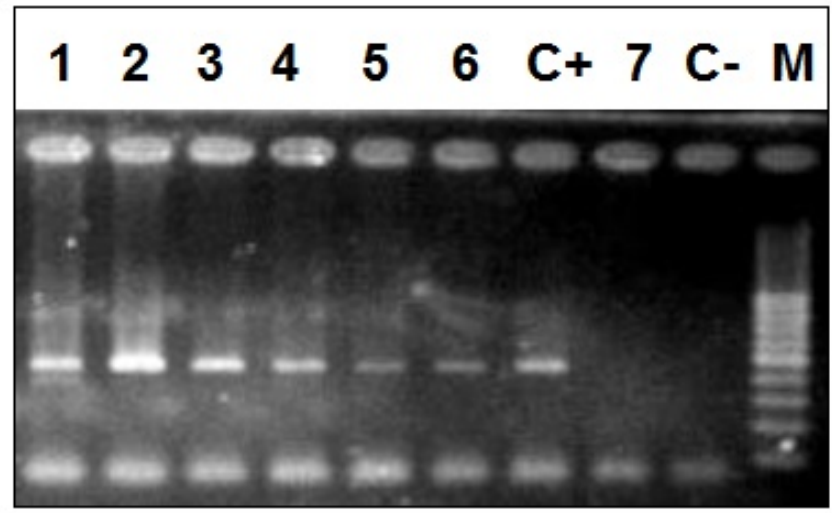

Figure 1. Electrophoresis of PCR reaction products of the DYS14 gene. The DYS14 gene fragment is $198 \mathrm{bp}$, and it was visualized in an ethidium bromide stained $2 \%$ agarose gel. 1 to 7 - samples from seven study patients. $\mathrm{M}=$ molecular weight marker, 50 bp ladder. Samples 1-6 amplified the 198 base pair band, indicating pregnancy with male fetuses. Sample 7 indicates a female gender. 


\section{RESULTS}

Among the 32 samples collected, 21 resulted in females and 11 in males. Only four samples showed false negative results. In those samples, the presence of Y chromosome DNA was not detected, however the fetus was male. All results incompatible with true fetal sex were collected from pregnant women at the 8th gestational week. In all four samples, the PCR failed to detect the Y chromosome. As shown in Table 1, the sensitivity profile was not sufficient to safely detect fetal sex at week 8 of gestation.

Table 1. Correct detection of fetal sex test by molecular analysis of maternal plasma according to gestational age.

\begin{tabular}{llll}
\hline Gestational age in weeks & n & Correct detection & Error \\
\hline 8 & 10 & 6 & 4 \\
$9-10$ & 6 & 6 & 0 \\
$11-12$ & 8 & 8 & 0 \\
$12-13$ & 8 & 8 & 0 \\
Total & 32 & & \\
\hline
\end{tabular}

\section{DISCUSSION}

The results we found are in accordance with the scientific literature, where the determination of fetal sex has an accuracy rate of about $97 \%$ from the eighth week of gestation, and the test specificity increases proportionally with gestational age (Sekizawa et al., 2001; Avent et al., 2006).

According to a study conducted by Kazachkova et al. (2019), failure to detect Y chromosome in maternal plasma in the first gestational weeks is probably related to the low concentration of free fetal DNA present in the maternal circulation. In this study, amplification of the SRY gene two weeks later indicated a significant increase in free fetal DNA concentration, proving greater test accuracy with increasing gestational age.

Besides the influence of gestational age, another justification proposed by Costa et al. (2001) and Levi et al (2003) for false negative result rates would be by the type of PCR used. Some faster PCRs with higher sensitivity levels, such as real-time PCR, offer the highest levels of safety so far and represent the safest amplification process. Thus, higher hit rates can be obtained, even at earlier gestational ages.

The type of PCR used our study was the conventional PCR, also known as semiquantitative. This method is based on amplification of target sequences, followed by agarose gel electrophoresis and has several disadvantages compared to real time PCR. Among them, we can list the result determination only at the end of the process of all cycles. In addition, another problem with this technique is that DNA is saturated at the end of the process. This implies that it is not possible to detect differences in the expression of certain genes, not allowing the observation of significant differences in gene expression. Taking into account these factors, it is considered crucial to standardize the number of cycles, which is quite variable and may lead to false negative results (Picchiassi et al., 2008; Nascimento et al., 2015). 
In contrast, the real-time PCR technique allows cycle-by-cycle detection with high sensitivity and specificity of the fluorescence intensity emitted as a result of amplification of the target DNA sequence. This feature enables comparative analysis of gene expression between samples early in the exponential phase of amplification, in which there is no saturation of amplification, thus eliminating a bias of the semi-quantitative technique (Nascimento et al., 2015). Research results of this type have allowed the clinical use of these tests, reducing the need for invasive techniques and ultrasound.

\section{CONCLUSIONS}

The determination of fetal sex from the 9th gestational week on had a sensitivity index considered satisfactory. It was also observed that the sensitivity and specificity of the tests increase with gestational age, resulting in lower chances of false negatives. In addition, it was possible to infer that the procedures involved in the analysis, such as the PCR procedure, have a great influence on the specificity of the result. The better the techniques employed, the greater the sensitivity and may have positive results with increasingly smaller gestational ages. Technological advances in genetics have brought encouraging results, making the use of free fetal DNA a promising method for obtaining fetal genetic material for prenatal diagnosis and monitoring.

\section{ACKNOWLEDGMENTS}

This research was funded by Funasdep (Fundação Nacional de Desenvolvimento de Ensino Superior Particular). We thank all those who directly or indirectly contributed to make this research possible.

\section{CONFLICTS OF INTEREST}

The authors declare no conflict of interest.

\section{REFERENCES}

Almeida P, Franco S, Guerra N and Moura P (2014). A nova era do rastreio pré-natal. Acta Obstet Ginecol Port. 8(3): 284-290.

Avent ND and Chitty LS (2006). Non-invasive diagnosis of fetal sex; utilisation of free fetal DNA in maternal plasma and ultrasound. Prenat Diagn. 26(7): 598-603. doi:10.1002/pd.1493.

Breveglieri G, Bassi E, Carlassara S, Cosenza, LC, et al. (2016) Y-chromosome identification in circulating cell-free fetal DNA using surface plasmon resonance. Prenat Diagn. 36: 353-361. doi: 10.1002/pd.4788.

Costa JM, Benachi A, Gautier E, Jouannic JM, et al. (2001). First - trimester fetal sex determination in maternal serum using real - time PCR. Prenat Diagn. 21(12): 1070-4.

Hyett JA, Gardener G, Stojilkovic-Mikic T, Finning KM, et al. (2005). Reduction in diagnostic and therapeutic interventions by non-invasive determination of fetal sex in early pregnancy. Prenat Diagn. 25(12): 1111-6.

Kazachkova N, Gontar J, Verlinsky O and Ilyin I (2019). Successful early fetal sex determination using cell-free fetal DNA isolated from maternal capillary blood: A pilot study. Eur. J. Obstet. Gynecol. Reprod. Biol. X. 3: 100038.

Levi JE, Wendel S and Takaoka DT (2003). Determinação pré-natal do sexo fetal por meio da análise de DNA no plasma materno. Rev. Bras. Ginecol. Obstet. 25(9): 687-690.

Nascimento S, Suarez ER and Pinhal MAS (2015) Tecnologia de PCR e RT-PCR em tempo real e suas aplicações na área médica. Rev. Bras. Med. 67: 7-19.

Picchiassi E, Coata G, Fanetti A, Centra M, et al. (2008). The best approach for early prediction of fetal gender by using free fetal DNA from maternal plasma. Prenat. Diagn. 28: 525-530. doi:10.1002/pd.2018. 
Sekizawa A and Saito H (2001). Prenatal screening of single-gene disorders from maternal blood. Am. J. Pharmacogenomics. 1: 111-117.

Sekizawa A, Kondo T, Iwasaki M, Watanabe A, et al. (2001). Accuracy of fetal gender determination by analysis of DNA in maternal plasma. Clin. Chem. 47(10): 1856-1858.

Zargari M, Sadeghi MR, Shahhosseiny MH, Kamali K, et al. (2011). Fetal Sex Determination using Non-Invasive Method of Cell-free Fetal DNA in Maternal Plasma of Pregnant Women During 6(th)- 10(th) Weeks of Gestation. Avicenna J. Med. Biotechnol. 3(4): 201-6. 